\title{
Development of Strategy for Digitalization of Scientific University Library
}

\author{
Zabara L.I. ${ }^{*}$ Yakina L.N. \\ Ural State Pedagogical University, Yekaterinburg, Russian Federation \\ *Corresponding author. Email: zabarali2011@gmail.com
}

\begin{abstract}
The authors turn to understanding some of the trends that define the phenomenon of "digitalization" in the University library, analyzing and highlighting didactic requirements and priority characteristics for the development of an electronic bibliographic product accompanied by the educational process of students.

The main strategic lines related to the methodology and methodology of creating and including this digital format of book communication in the educational environment in terms of a positive impact on the reader (technogenic and humanistic factors) are systematized using the example of implemented bibliographic products on topical General cultural topics and debatable problems of history in the IIC-Scientific library of the Ural state pedagogical University. A special role is given to the quality of the bibliographic product as proactivity. The principles outlined in the theoretical and practical design of digital bibliography products on specific humanitarian topics for students cover selection, visual solutions with the introduction of semantic accents, processing and structuring of content, in accordance with the pedagogical orientation of the library and the University.
\end{abstract}

Keywords: digitalization in the library, bibliographic services, electronic educational product

\section{INTRODUCTION}

Technological and humanitarian development of University libraries is integrated into the educational space of dynamically developing higher educational institutions. In the flow of innovations, it is important to try to reflect and identify the driving forces of updating processes by specialists, especially in humanitarian universities, in the era of digital information and communication of subjects. Strategizing the digital future of the University library is "inscribed" in the realities and prospects of the educational institution:

"University libraries do not operate in isolation from their host institutions. Their development strategy needs to align closely to that of their institution and their vision of the future needs to fit that of their institution. ... and this should not only be reflected in changing practices and priorities but also strategic direction and visions of the future library" [1].

Digitalization processes in higher education raise a number of questions and problems related to both the technological and value - semantic components of innovation in a constantly changing environment, in which the library of a pedagogical University is designed not only to provide the reader with a modern set of information and communication services, but also to contribute to the professional and personal development of a teacher, researcher.
One of the problems, we believe, based on the statements of domestic and foreign experts in the library sphere about the dominance of bookless communication in the era of global technological civilization [2], is that digital transformations in libraries of higher educational institutions should not allow skewing the movement only in improving the technological environment, but purposefully develop the humanitarian component of innovative changes. Both specialists and library users understand this problem. For example, foreign experts analyzed and summarized statements about the attitude to speeding up the process of digitalization in education, collected during a structured targeted survey in one of the European universities: "Although there was some agreement that the pedagogical fundamentals would not change significantly there was widespread agreement that the disruptive influence of digitalization would need addressing in the form and/or content of teaching" [1]. We consider it very important that the negative impact of total digitalization can mitigate and level the "pedagogical foundations", that is, the principles of humanistic pedagogy.

From the humanitarian point of view of the problem, digitalization in the University library is understood as a process of organic purposeful embedding of digital library and bibliographic service products in an open educational environment that requires consideration of the specifics of their development, implementation and presentation to readers, taking into account general pedagogical goals and professional development tasks. This involves the development of strategies, basic approaches, principles 
and directions of meaningful work with the library and bibliographic product of digital format, understanding its role, functioning, and value - impacting potential, in our case - in the pedagogical aspect, which involves "working with values and meanings".

\section{RESEARCH METHODOLOGY OF DESIGNING INFORMATION AND COMMUNICATION SUPPORT FOR FUTURE EDUCATION}

Scenarios of digitalization and technological renewal in the University library are closely related to the concept of the federal project "Digital educational environment", aimed at creating "conditions for the introduction of a modern and secure digital educational environment by 2024, which provides the formation of self-development and self-education values for students of educational organizations of all types and levels..." [3], where the implementation of the target model of the digital educational environment is indicated.

The model of digital library and educational environment is associated with such trends in information and communication support for readers as digitalization, virtualization and visualization. IIC - Scientific library of USPU develops theoretical approaches and research practice of creating an electronic educational bibliographic product that meets the requirements of classical bibliography as a systematization of sources, the features of book communication as a value - personal and didactic expediency, which immediately leads library specialists to the educational space of communication, finding meanings, dialogue with readers on the basis of the presented information and library complex.

The analysis of the effectiveness of using traditional bibliographic products in serving USPU library readers showed the demand for literature lists (fixed bibliographic information on a specific topic or issue) in the scientific activities of the teaching staff and, conversely, the low attractiveness of this form of presenting information for students.

The new generation of readers - the youth audience - is characterized by such preferences in the perception of the material as dynamism, visualization, interactivity, compactness, structure, convenience and speed of access. These needs are met by products based on the use of information - computer and Internet technologies and web services in the library Prezi.com you can use it to create interactive multimedia presentations with a non - linear structure - virtual reviews of publications in an interactive format.

Electronic educational bibliographic product (EEBP), as a rule, occurs at the intersection of coordination of requests and needs of teachers of departments, general cultural and pedagogically significant information occasions and topics, opportunities for specialists of IIC-NB (qualifications, ICT technologies), also as one of the effective ways to disclose and promote the library's Fund for readers "in numbers".

Understanding changes in thinking, perception of information by the "digital generation", which is "familiar with the transition from the real to the virtual and back", is characterized by an increase in the speed of viewing reading as a leading in the cognitive activity of students, along with the expansion of the arrays of information that can be mastered by a person (let's call it a "technogenic" factor), the University library will be able to meet the challenges of the digital age without destroying the integrity of the individual, thanks to the strategy in providing library services, based on the principles of pedagogy (the humanistic factor).

In the sphere of bibliographic services, reformatting in the presentation of information was focused on such characteristics as mobility, visualization, which became possible with the use of interactive online services and programs in digital formats.

It should be said that the modernization of the role and activities of the University library in the digital age, generalizing methodologically, can be provided by such service and interaction with readers, which is based on changing the very nature of library activities, moving from the accumulation of resources to the introduction of proactive library services. By proactivity, in the general scientific sense, we understand the orientation of the library to change the perception and needs of a person, including his conscious choice. For the library, this property is realized as a strategic dynamic orientation of its activities, analysis of the current situation, forecasting, modeling of processes and products, constant reflection and production of innovative ideas on the principle of openness of the library and its resources to the reader, which is especially important in the digital age. In order to ensure the proactivity of the bibliographic product (review, list, index), the most traditional type of service, in our case, you should turn to the question: how is this product focused on digital education? Can EEBP become the basis of information and bibliographic practice in an educational institution?

\section{RESULTS AND DISCUSSION: INNOVATIVE EDUCATIONAL BIBLIOGRAPHIC PRODUCT AND ITS POTENTIAL}

One of the priority directions of IIC - NB development in the implementation of the state educational policy is the introduction of digital resources and visual models of information representation using modern technologies to increase its accessibility for students, teachers, researchers and researchers. The library's website contains subscription - based systematized electronic information resources and its own library and bibliographic products, generation of current publications according to various selection criteria (USPU scientific journals, scientific publications indexed in Scopus and Web of Science, etc.), 
which solve the key tasks of information and methodological support of scientific and educational activities

In support of the educational process of the University, the main types are educational - auxiliary and recommendation bibliography. The creation of electronic educational products is implemented in the format of interactive computer presentations for students (thematic indexes in interactive mode, visualized reviews - online) to promote educational, methodological and scientific publications available in the fund and placed in electronic library systems (ELS).

Since 2013, the library has been producing thematic reference indexes in digital format (electronic educational bibliographic product - EEBP), understanding the special characteristics of the product and its presentation to students. The practice became an impulse for theoretical research, analysis and modeling of the content and functional components of EEBP from the perspective of the requirements of pedagogical (influencing) and educational (cognitive, reflexive) reality: in the promotion of reading, local history, civil and patriotic education, and the study of current socio - historical topics.

The presentation of bibliographic material is changing in the modern educational environment of the Universitydynamic, rich, open, digital. Demonstrations of electronic bibliographic illustrated products in the format of presentations are aimed at further holding events in a discussion form, communicating with readers, and we strive to ensure that the coverage of publications and systematization of sources, make them full - fledged indexes and expand the understanding of publications on the topic. Electronic illustrated bibliographic indexes in interactive online mode cover a significant volume of recommended reading repertoire, concentrate information about publications from a certain angle: based on the goals and objectives, categories of readers, the specifics of these areas; developing the general cultural competence of future teachers. The role of the pedagogical aspect of presentation in book communication is very important.

In 2015, a number of bibliographic illustrated indexes were made in the format of a computer presentation. "Biblioguide for the Sverdlovsk region. 80 years of the Sverdlovsk region" [4] describes 60 specially selected publications of various types from the IIC-NB Fund, recommended for the development of the history and dominant modernity of the Ural region, grouped into sections on history, geography, education and culture, economy and industry. The materials are placed in accordance with the main idea - to conduct a virtual "tour", "journey" on the main facts of history and the most significant phenomena in the life of one of the largest municipalities of the Ural Federal district. Visual design (backgrounds, illustrative series), the ability to highlight content elements - text and images in an interactive format are aimed at creating a multi - faceted "image of the place" for students, aimed at a more detailed introduction to the topic, stimulating reading of popular and scientific publications for in - depth study of the material.
Online presentation "Orthodox churches and monasteries of Yekaterinburg" [5], dedicated to the history of temple architecture of the Ural capital includes more than 40 modern publications on the topic - books on Ural architecture, reference books on regional culture. There is a function for reading text fragments about significant monuments (scanned copies) and viewing illustrative material with detailed images. This expands the functional palette of the bibliographic index, which is informative and visually rich in a computer presentation, so that it can be used as a representative source and methodological guide on the topic.

The presented bibliographic visualized products are in demand among students of Humanities, which is confirmed by the increasing number of views on the IIC NB website and the page in the social network. The use of these products in library and bibliographic classes, during meetings and dialogues on various topics with University students and schoolchildren, showed that the digital illustrated bibliographic index serves as a semantic integrator together with other forms of work with readers and with library and pedagogical technologies in accordance with the priority direction of educational work of the University.

We have seen that the industry standards and functions of classical bibliography in the information support of scientific activities of specialized University departments undoubtedly relate to the creation of electronic bibliographic products for the study of current topics by students. However, its targeting introduces features related to the search, selection, processing, systematization, design, preservation, dissemination and provision of users with representative and reliable information for solving educational and intellectual research tasks in the Humanities of training future teachers. This was taken into account in the further development of educational materials, including digital and library materials.

In 2017, the library in the socio - historical project "If not 1917 , if not 1937...", implemented at USPU, understanding the role of bibliography in the study of the resonant theme of the revolution in Russia, which attracted special attention of researchers, students, and the public, assisted in preparing a wide range of readers to discuss problematic issues during discussions, round tables, and debates. Virtual bibliographic review "To the 100th anniversary of the October revolution" [6] combined journalistic and scientific publications of the IIC - NB foundation on the topic of the Russian socialist revolution. It was necessary to present the dynamics of research, the transformation of assessments of the events and significance of the October revolution by domestic and foreign historians of different socio - historical epochs to readers in an attractive interactive form.

In this regard, the following principles of material selection were developed and adopted: integration and differentiation of sources, integrity and allocation of unique materials on the topic, visual solution with the introduction of verbal semantic elements to stimulate the study, understanding of contradictions, reflection of various interpretations in the consideration of this 
phenomenon. To increase interest in in - depth study of issues related to the further impact of the events of 1917 in Russia on the course of world history, the books are grouped into sections: "Memoirs and assessments of the revolution by contemporaries", "Publications reflecting the assessment of the October revolution by historians of the Soviet period", "post - Soviet historical publications"; quotes from texts are provided. Consultations were held with leading teachers of historical departments of USPU; orienting future teachers-historians to improve their methodological competence in teaching one of the most complex topics of Russian history, based on a new educational and methodological complex for the study of history at school "History of Russia" for grades 9 - 10, corresponding to the federal state educational standard of basic general education.

These principles formed the basis for creating a virtual review of publications of a bibliographic nature in the computer presentation "You can not be forgotten: we read books about the tragedy of the Holocaust" [7]. To attract readers to an in - depth study and understanding of the topic that carries a tragic experience of history and a serious spiritual and moral meaning, the EEBP presented a selection of 30 publicistic and scientific books, scientific and methodological articles in pedagogical periodicals from the IIC-NB Foundation (with access to their electronic versions in the EBS); quotes are given from the works of famous scientists who actualize the problem areas of research on the topic. Books and bibliographic information about them are grouped into sections: "The memories of witnesses. Jewish authors about the Holocaust", "Russian scientists about the Jewish tragedy of the 20th century", "Publications of foreign researchers of the sociology about the Holocaust".

The sections are formed in such a way as to show different perspectives of seeing events and evaluating them as history lessons; to deepen the understanding of the structure of knowledge on the topic; to highlight aspects of research work and methods of conducting conversations in school. The structure of the review is set by the selected principles of selection of sources to show the view of representatives of the people who suffered in the tragedy of the Holocaust; the experience of understanding events in Russian historiography; the reflection of European humanist scientists; the methodological component in the development of the topic by students. The spiritual and moral assessment is displayed in the visual design of the slides. The resource is used in remote access mode: viewing content; reading bibliographic records and annotations, quotes with links (URLS) to the texts of electronic versions of submitted publications in full - text databases in the EBS used by USPU by subscription.

The humanistic principles of pedagogy are implemented in the fact that the book review in digital format is effectively used as a methodological tool for organizing classes, round tables, seminars about the tragedy of the Holocaust, including the preparation and conduct of tolerance lessons in the USPU library and in educational institutions. In our opinion, at the stage of familiarizing the readers with the books it motivates them to comprehend the reasons, the essence of the processes and understanding of the lessons of the Holocaust, the effect on the ideological level due to the semantic accent, selection of publications, content annotation, the decoration presented in the review books (meaning dominant, the axiological approach in pedagogy). In the presentation of this EEBP, an intellectual and dialogical form of communication was used (discussion on the issues raised, search for solutions to methodological issues for organizing discussions with students on the problems of ethnic and national conflicts that will draw students' attention to acute social phenomena in modern society. This is how we solve a set of educational tasks in the "University - school" succession based on working with a digital bibliographic product.

\section{STRATEGIC GENERAL HUMANITARIAN GUIDELINES IN THE DESIGN OF AN ELECTRONIC EDUCATIONAL BIBLIOGRAPHIC PRODUCT}

Digital data representation, processing and use can significantly improve efficiency, quality and productivity in the library sector, as well as in other different types of production, technologies and services, compared to traditional forms.

In library and bibliographic activity with its pedagogical orientation, we will highlight the main initial moments in the strategy of designing an electronic educational bibliographic product (EEBP) and general principles of strategizing, which should be used to build a model of thematic bibliographic electronic products of educational type, taking into account their features in the preparation of students, determine the logic and possibilities of its implementation.

We will take into account the main factor that if quantitative and qualitative indicators (coverage of publications, relevance) are important for ensuring scientific and research activities in a bibliographic product, which determine its cognitive component, then its effective impact (motivating, stimulating, educating), aimed at increasing the cognitive activity of the subject, becomes no less important in the construction of the EEBP content.

he creation of digital products in the field of bibliography to support educational activities in a pedagogical University is characterized by a focus on:

1) study of socially significant topical, debatable topics in the study of history;

2) formation of spiritual and moral values of students;

3) pedagogical expediency and internal logic in determining the possibility of EEBP (the principle of subordination of design to educational goals and needs, interests of the consumer of products and services);

4) assistance in solving educational and scientific methodological problems through the promotion of high - 
quality literature, modern publications that meet the standards and requirements of accessibility and security of educational content as a function of bibliography in higher education (the principle of multi - variant solutions with a reasoned choice of sources and reasonable structuring to check intermediate and final solutions in the design of EEBP);

5) pedagogical specificity in the implementation of cognitive, developmental, educational functions of the University library through the design of structures, relationships of content elements in the structure of EEBP (word images, section names, their sequence, bibliographic records/data, citations, annotations, texts, links, visualizations), actualizes the introduction of library and pedagogical technologies (the principle of unity and correspondence of the functioning of the object unitssources and channels of information dissemination, information and communication means for obtaining new knowledge).

It is possible to point out the universal possibilities and means of using a bibliographic product designed on strategic orientation principles - a representative safe source and a "semantic core" in actualizing the study of a specific historical topic for solving research and educational and educational tasks in a pedagogical University.

1) Digital library products-EEBP at the University orient students to the optimal subject bibliographic search in the real and electronic sphere of IIC - NB, reducing the risk factors of negative impact of "information noise", overcoming information entropy by updating information. Original electronic bibliographic educational and auxiliary publications are included in the continuous process of information support of education and science that is why cooperation with USPU departments is formed.

2) Semantic visualization as a tool is one of the ways to improve the development of heterogeneous information, including captured in visual - spatial memory. This is important for the professional training of future teachers who are able to design effective educational products and

\section{CONCLUSION}

In the theory and practice of developing strategic lines in the digital representation of information, creating an electronic educational bibliographic product, we have outlined its features and role in the digitalization of education. In designing the University library EEBP as a special type of manuals, which are a symbiosis of bibliographic indexes, virtual reviews and online exhibitions, we found that to increase the attractiveness and effectiveness of the necessary: the formation of factors to increase students' interest in the methodology of studying the most complex, controversial topics of national and world history, methods of teaching them at school for the development of research culture of the future teacher; strengthening the axiological aspect in worldview education based on spiritual values and civic position of young people; integration of sources, activities of students in an information - congested environment.

3) Experience in developing digital products and further search for means of using and including EEBP in information and educational content for students confirms that simultaneously with the strengthening of the technological component, the library of a pedagogical University increases the integrating, interpretive role of bibliography in modern interdisciplinary knowledge, in the movement "from bare fact to the meaning of history" at all stages: design, creation and use of a bibliographic information product. It is not merely to inform, but in a conceptual solution to "present" material - body of publications on the subject (the process of searching various types of documents, their selection, transformation, structuring, processing, transmitting, mediation), in reflection of the integrity and systematic study and understanding of the historical process, the prospects and possibilities of historical knowledge, in confirmation of the idea of librarian scientist N. F. Fyodorov that the bibliography itself does not give knowledge, but it is the "key to knowledge" [8]. Its modern role in the educational environment is becoming more complex: it requires "involvement" in the process of communication with readers at an informal level, not only information, but also value-semantic communication of generations.

n 2018 - 2019, based on the highlighted strategic principles, we developed the structure and content of the EEBP with proactive services in promoting high - quality children's literature for future teachers to familiarize themselves with, especially in the Patriotic education of students, revealing book resources about the feat and tragedy of the great Patriotic war to the 75th anniversary of Victory. Electronic educational bibliographic products were presented and disclosed in live communication to students, who discussed the structure, content and features of visualized virtual reviews of publications of the IIC Scientific library.

bibliographic information about the Foundation's documents - with access to their electronic full - text versions in the EBS (coverage and complementarity in the design of a thematic resource); creation of visual images, original infographics for assimilation and consolidation of a large amount of information; identification of indicators/evaluation criteria in the analysis of the relevance of EEBP.

These digital products correspond to the general pedagogical goals and principles identified by us, which allows us to consider the bibliographic source representative for solving a set of educational tasks in a specially organized book communication (achieving personal, subject and meta - subject educational results). The potential of EEBP, which plays the role of a semantic integrator, regardless of the depth of its digitalization in 
each case, is, to a greater extent, in its axiological vector direction on translated meanings and values, thereby not reducing the understanding of digital bibliography to the sum of information and communication technologies, strengthening the "human-oriented" resource of book communication. The strategic approaches and principles developed by us will be used to organize new library programs for the "digital generation", developing the idea of proactivity of digital services and products in a modern University library.

In implementing digitalization in information and bibliographic work, as we have shown by the example of the library of a pedagogical University, in order to maintain the balance of its technogenic influence and humanitarian perspective, the following lines are necessary: professional - pedagogical, socio - cultural, communicative, analytical, integrative, facilitation, mediation. These strategic directions in creating digital products in an open educational environment combine and harmonize content - semantic, functional and instrumental components that are focused on the needs of the reader. The experience of the IIC - Scientific library can be useful to University libraries in understanding the transformation processes of the information and bibliographic sphere, preserving the unity and values of the pedagogical basis of education.

In general, experts of the library community note the positive and negative impact of the spread of digital technologies: they increase the efficiency of providing services, reveal qualitatively new opportunities for library services, however, "library and information services also

\section{REFERENCES}

[1] Boyce, G., Greenwood, A., Haworth, A. and Hodgson, J. (2019), "Visions of value: Leading the development of a view of the University Library in the 21 st century" ["Cennostnye predstavleniya: vedushchie $\mathrm{k}$ razvitiyu vzglyada na universitetskuyu biblioteku $\mathrm{v}$ 21 veke"], Zhurnal akademicheskogo bibliotechnogo dela, vol. 45, Issue 5, September. DOI: https://doi.org/10.1016/j.acalib.2019.102046 (in Russian).

[2] Sokolov A. V. (2012), The library and humanism: the mission of the library in the global technological civilization [Biblioteka i gumanizm: missiya biblioteki v global'noj tekhnogennoj civilizacii], Interregional Library collector, Moscow, pp. 390-395. (in Russian).

[3] Federal project "Digital educational environment", National project "Education" (2018), [Cifrovaya obrazovatel'naya sreda, Nacional'nyj proekt obrazovaniya], Ministerstvo obrazovaniya Rossijskoj Federacii, Moscow, available at: https://edu.gov.ru/national-project (in Russian). include processes that are impossible without the participation of a person who has such qualities as the ability to anticipate, emotional experience, intuitive forecasting" [9].

The active introduction of digital tools (digital transformation or digitalization) in the educational environment is less spontaneous, and specialists are now aware of the need for structured and project - based approaches in the development and implementation of digitalization strategies. Examples of successful implementation of digitization projects for library and information services "demonstrate the readiness of libraries to move to a new level of development" [9].

The introduction of digital formats and their inclusion in the humanitarian dialogue with readers, the creation of an up - to - date digital bibliographic repertoire of literature of an educational and auxiliary nature requires an understanding of the new role and competence of a specialist - librarian, professional bibliographer. For example, in the formation of the necessary project competence of future specialists in the digital society "the structure of library workers' project competence (value motivational (axiological), knowledge - content (cognitive), technological (activity - practical) components) is specified" [10]. A combination of stable personal, cognitive, and professional motives, a conscious positive attitude to the activities of the project, and a specialist's readiness to implement it will ensure the solution of strategic issues of digital transformation of libraries of higher educational institutions that require the interaction of all subjects of science, culture, and society.

[4] Biblioguide in the Sverdlovsk region (2015), 80 years of the Sverdlovsk region ["Bibliogid po Sverdlovskoj oblasti. 80 let Sverdlovskoj oblasti”], Informacionno-intellektua'nyj centr Nauchnaya biblioteka UrGPU, available at: http://library.uspu.ru/item/3272-k-85-letiyusverdlovskoj-oblasti-intellektualnoe-puteshestvie-s-iitsnauchnoj-bibliotekoj (in Russian).

[5] Orthodox churches and monasteries of Yekaterinburg (2015) ["Pravoslavnye hramy i monastyri Ekaterinburga"], Nauchnaya biblioteka - v pomoshch' duhovno - nravstvennomu vospitaniyu available at: http://library.uspu.ru/item/2798-iitsnauchnaya-biblioteka-v-pomoshch-dukhovnonravstvennomu-vospitaniyu (in Russian).

[6] To the 100th of the October Revolution (2017), ["K 100-letiyu Oktyabr'skoj revolyucii”], K 100 - letiyu Oktyabr'skoj revolyucii available at: http://library.uspu.ru/item/3009-k-100-letiyuoktyabrskoj-revolyutsii-virtualnaya-vystavka-izdanij- 
fonda-iits-nauchnoj-biblioteki-v-aktualnom-proekteurgpu (in Russian)

[7] Cannot be forgotten: we read books about the Holocaust tragedy (2017) [“Zabveniyu predat' nel'zya:chitaem knigi o Holokoste"], Nauchnaya biblioteka - uchastnik Mezhdunarodnogo konkursa rabot Pamyat' o Holokoste - put' $\mathrm{k}$ tolerantnosti, available at: http://library.uspu.ru/item/3075-iitsnauchnaya-biblioteka-uchastnik-mezhdunarodnogokonkursa-rabot-pamyat-o-kholokoste-put-ktolerantnosti (in Russian).

[8] Ilyina, E.V. (2019), Bibliography through the eyes of N. F. Fedorov: "from imaginary knowledge to real knowledge" ["Bibliografiya glazami N. F. Fedorova: “Ot mnimogo znaniya k znaniyu dejstvitel'nomu”], Bibliografiya i knigovedenie, vol. 2 (421), pp. 147 151.

[9] Nescheret, M. Y. (2019), Digitalization of service processes in libraries is already a reality ["Cifrovizaciya processov obsluzhivaniya v bibliotekah - eto uzhe real'nost"'], Bibliosfera, vol. 2, pp. 19 - 25, DOI: https://doi.org/10.20913/1815-3186-2019-2-1925 (in Russian).

[10] Pryima, S. M., Anishchenko, O.V., Yuan, D.Y. (2019), "Formation of the project competence of future specialists in information, library and archive services in a digital society" ["Formirovanie proektnoj kompetentnosti budushchih specialistov v informacionnom, bibliotechnom, i arhivnom obsluzhivanii v cifrovom obshchestve"], Informacionnye tekhnologii i sredstva obucheniya, vol. 70(2), pp. 121-140, DOI: https://doi.org/10.33407/itlt.v70i2.2639 (in English). 